\title{
KARST HYDROGEOLOGIC INVESTIGATION OF TROUT BROOK
}

\section{Joel T. Groten}

U.S. Geological Survey (University of Minnesota Graduate School Project), 2280 Woodale Drive, Mounds View, MN, 55112,USA,jgroten@usgs.gov

\section{E. Calvin Alexander Jr.}

University of Minnesota, 450 McNamara Alumni Ctr. 200 Oak St. SE, Minneapolis, MN, 55455, USA, alexa001@umn.edu

\section{Abstract}

Trout Brook in the Miesville Ravine County Park of Dakota County Minnesota is the trout stream with the highest nitrate concentration in the karst region of southeastern Minnesota. Water quality data from 1985 and 1995 (Spong, 1995) and from 2001, 2002, 2006, 2010, and 2014, collected by the Dakota County Soil and Water Conservation District (Dakota SWCD, 2014) document an increasing level of nitrate in Trout Brook. A karst hydrogeologic investigation was designed to measure nitrate levels at sampling points along the stream and to increase our understanding of the source and movement of nitrates throughout the length of Trout Brook. Eighteen springs and seeps have been located in the Main Branch and tributaries of Trout Brook. A previously unreported flowing section and stream sieve, Weber Sieve, were found above what had been thought to be the head of perennial flow in the East Branch of Trout Brook. Two new sinkholes developed after the 14-15 June 2012 flood in a field northeast of the East Branch of Trout Brook. This investigation included regular monitoring of major anions in the streams and springs, synoptic stream flow measurements, and a dye trace of a sinking stream in the Trout Brook drainage.

The initial assumption was that the majority of the baseflow of Trout Brook was from discrete springs. However, synoptic baseflow and nitrate measurements show that only 30-40 percent of the total flow in Trout Brook is from discrete springs, and the rest appears to be from distributed groundwater discharge directly into the stream. Both the discrete springs and the distributed recharge occur along reaches of Trout Brook that drain the significant high transmissivity zone near the bottom of the regionally important Shakopee aquifer. Dye traces have confirmed flow-paths from Weber Sieve to LeDuc and Bridgestone Springs and have begun to define springsheds for these head water springs. Nitrate concentrations and chloride/bromide ratios decreased systematically from the upstream springs to the downstream springs.

The nitrate concentrations have been increasing at four springs from 1985 to 2014 and at two surface sampling points from 2001 to 2014. The nitrate concentration of another surface sampling point increased from 2001 to 2006, decreased from 2006 to 2012, and increased from 2012 to 2014. Snowmelt and rainfall runoff was sampled on 2 March 2012 and showed no detectable nitrate in the runoff from a watershed with no row-crop agriculture, but elevated nitrate was detected in an adjacent watershed with row-crop agriculture. All of these trends illustrate the dominance of agricultural sources of nitrate in Trout Brook.

\section{Introduction Karst}

Complex surface and groundwater interactions are dominated by karst processes in southeastern Minnesota. Karst features often include caves, sinkholes, springs, stream sieves, and sinking streams. A springshed is the subsurface and surface areas that provide the discharge to a spring. A stream sieve describes a losing reach of a surface stream where specific water sinking points, stream sinks, are not evident. Karst features result from water containing carbonic acid which dissolves the carbonate in soluble bedrock. Water quality is a concern because karst features allow rapid groundwater velocities and short residence times. Karst springs provide the source water to premier trout streams in southeastern Minnesota. Trout Brook in the Miesville Ravine Park Reserve in southeast Dakota County and south of Miesville, Minnesota is one of these trout streams.

\section{Location, Geology, and Topography}

Trout Brook (Figure2) is located in the southeastern part of Douglas Township (T113N, R17W) of Dakota County, south of Miesville, Minnesota in the Miesville 
Ravine County Park. The area is underlain by a thin cover of flood plain alluvium, colluvium and Illinoian glacial outwash, loess and till (Hobbs et al., 1990). The glacial sediments rest unconformably on the lower Ordovician Shakopee Formation of the Prairie du Chien Group (Mossler, 1990). The Shakopee Formation is a mixture of limestone and dolomite with the New Richmond Sandstone near the bottom of the formation.

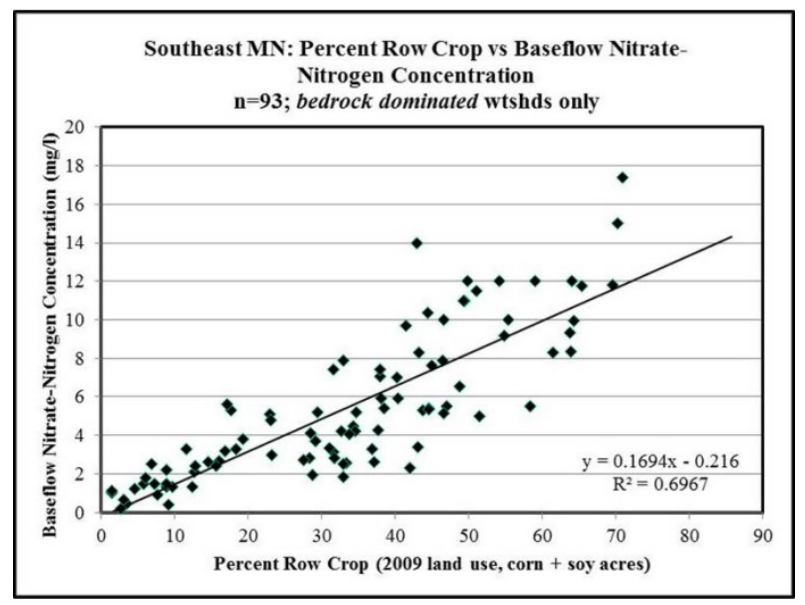

Figure 1. Baseflow nitrate-nitrogen concentration as a function of the percentages of row crop agriculture in the karst region of southeaster Minnesota.

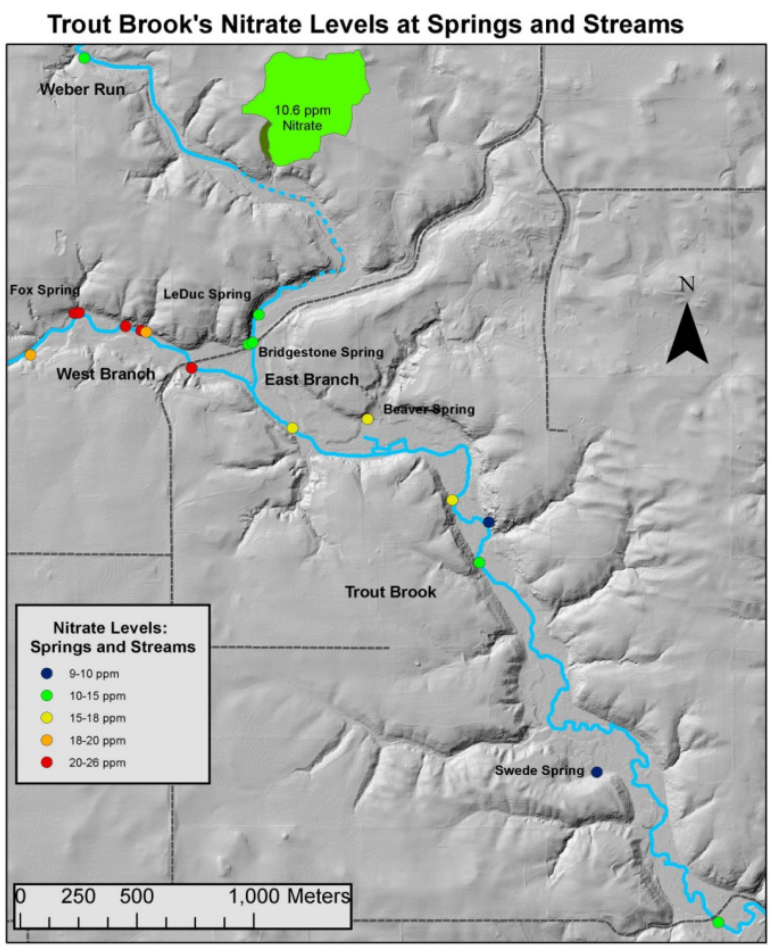

Figure 2. Trout Brooks streams, springs, and nitrate levels.
The Shakopee Formation unconformably overlies the Oneota Dolomite.

The Shakopee and Oneota Dolomite collectively form the Prairie du Chien aquifer, which is one of the most heavily used aquifers in Dakota County. An unconformity between these two formations represents a 10 million year subaerial erosion episode that left a high transmissivity zone (HTZ) of significantly enhanced porosity and permeability in the top of the Oneota. During and after the deposition of the Shakopee, karst solution processes expanded the HTZ up into the lower Shakopee. Runkel et al., (2003) and Tipping et al., (2006) report that this mid-Prairie du Chien HTZ is one of the primary features of the hydrostratigraphy of southeastern Minnesota. The source water for Trout Brook drains directly from this high transmissivity zone along bedding plane fractures, and through solutionally enlarged porosity and permeability and anastomosing karst conduits.

The Trout Brook surface watershed is largely an intensively cultivated gently rolling upland. The main land use type in the Trout Brook watershed is row-crop agriculture, and many farmers irrigate their crops due to the sandy soil. Livestock feedlots in the watershed are also potentially significant sources of nitrate. Very little surface water flows on the upland except during spring snowmelt and after the largest and most intense precipitation events. Most routine precipitation not consumed by evapotranspiration rapidly infiltrates to groundwater. South of Meisville the surface drainage abruptly incises steep-sided valleys to form the West and East Branches of Trout Brook. The East and West Branches join to form the Main Branch of Trout Brook in the Miesville Ravine Reserve Dakota County Park. The lower reaches of both branches of Trout Brook and the Main Branch widen downstream. All branches of Trout Brook meander across steep-sided, flat-bottomed valleys.

\section{Historical}

Spong studied Trout Brook, Dakota County, in 1985 and 1995 . He analyzed water chemistry at four springs (Beaver, LeDuc, Fox, and Swede Springs) in 1985 and two springs (LeDuc and Swede Springs) in 1995. The two sampling events in 1985 and 1995 were collected during baseflow periods (with no significant stormflow) in years with normal precipitation (Ron C. Spong, written communication, 2012). Flow rates were measured at Trout Brook's springs and streams in 1985 
(Spong, 1995). These data are important because they document water quality of the springs 27 and 17 years ago; data points that are critical in defining water quality time trends.

The Dakota County SWCD measured baseflow and obtained grab samples during storm events at Trout Brook during 2001, 2002, 2006, and 2010. Flow measurements were taken to characterize low flow and stormflow. The water samples were analyzed for typical water quality parameters and were reported to the State of Minnesota. Automated stage monitoring was also in place, but the data is suspect due to the flashy nature of this stream (Dakota Co. SWCD, 2010).

\section{Row-Crop Agriculture Versus Nitrate}

Reactive nitrogen is an environmental concern. In the hydrosphere it can lead to eutrophication, toxic algae blooms, and hypoxia. In the atmosphere it contributes to acid rain, deposition of nitrogen in forests leading to nitrogen saturation which can alter the soil, and global warming. Reactive nitrogen can also be harmful to humans due to air pollution and contamination of drinking water. The U.S. Environmental Protection Agency (EPA) reports that greater than 10 parts per million (ppm) of nitratenitrogen in drinking water can have adverse health effects (U.S. EPA, 1990). (In the rest of this work, the word "nitrate" is synonymous with "nitrate-nitrogen".)

The Hastings Area Nitrate Study (HANS, 2003) was carried out in Dakota County, MN near the study area. That study highlights the nitrate contamination problem in groundwater and considered three possible sources: row-crop agriculture, feedlots, and septic systems. Groundwater samples collected in 2000 showed nitrate levels varied among the aquifers. The Shakopee aquifer had the highest concentration of nitrate at $15 \mathrm{ppm}$, the Quaternary aquifer was next at $8.7 \mathrm{ppm}$, and the Jordan aquifer had the lowest at $1.85 \mathrm{ppm}$.

Figure 1 from Watkins (2011) shows the percent of rowcrop agriculture plotted against nitrate plus nitrite in streams at baseflow in the karst region of southeastern Minnesota. Groundwater discharge supports the baseflow of streams and rivers in this karst region, with discrete springs typically providing a substantial portion. A linear relationship is present with $\mathrm{R}^{2}$ value of 0.70 . This indicates a strong relationship between the percentages of row-crop agriculture in southeast Minnesota watersheds versus the nitrate concentrations in streams at baseflow. Trout Brook was selected for study because it has the highest nitrate concentration at baseflow of monitored streams in southeastern Minnesota. Trout Brook is the uppermost data point, below $18 \mathrm{mg} / \mathrm{L}$, on the above graph.

\section{Monitoring}

An initial survey of Trout Brook occurred in February 2011, and a second round of sampling occurred in July 2011. A systematic water sampling campaign began in October 2011 and ended in October 2012

Eighteen discrete springs documented along Trout Brook are shown in Figure 2. All of the springs emerge where the steep valley walls meet the flat valley floor. All but two of the springs, Beaver and Swede, emerge where Trout Brook has meandered up against the base of the valley walls. Beaver and Swede are buffered from Trout Brook by beaver dam induced wetlands.

\section{Geochemistry}

The field and analytical methods used in this work are described in Alexander and Alexander (2011). The nitrate concentrations at Fox, LeDuc, Beaver, and Swede Spring have been increasing with time (Figure 3). The nitrate concentration of Fox Spring is increasing at the greatest rate of $0.42 \mathrm{ppm} /$ year while the concentrations at Beaver, Swede, and LeDuc Springs are increasing at rates of $0.25,0.18$, and $0.11 \mathrm{ppm} / \mathrm{year}$, respectively. These rates were calculated over a 27 year span. The rate of increase for Fox Spring is almost twice as high as the next highest rate, that of Beaver Spring. These increases are likely due to changes in farming practices over time and the intensity of farming on the contributing springsheds.

Figure 2 shows the concentrations of these four springs compared to the other springs in Trout Brook as colorcoded dots. The springs discharging into the West Branch of Upper Trout Brook have the highest nitrate levels. The springs discharging into the East Branch of Upper Trout Brook have low to moderate nitrate levels. The three yellow dots on the Main Branch indicate moderate nitrate levels and the springs further downstream have the lowest nitrate levels.

The nitrate concentrations in spring resurgence appear to be controlled by location. This relationship is likely 


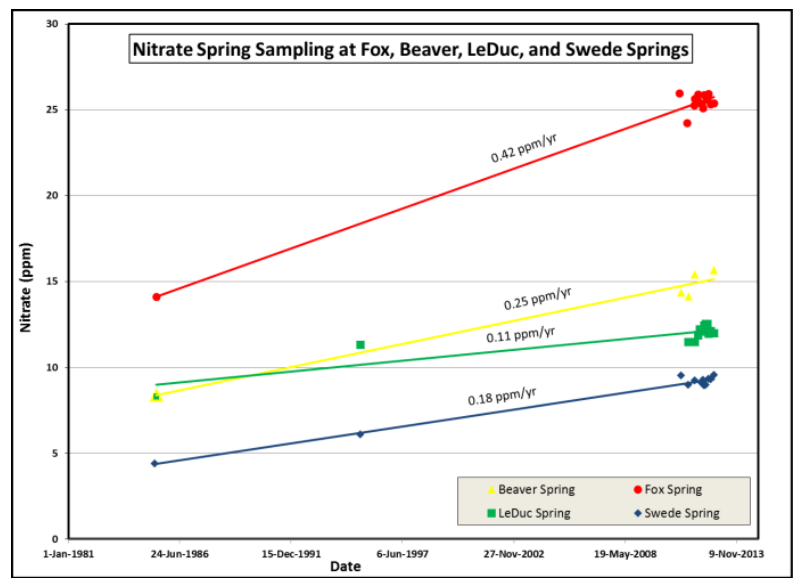

Figure 3. Nitrate concentration as a function of time at four springs.

determined by the springshed of each spring. The springs further downstream probably involve longer flowpaths draining deeper parts of the aquifers. The contributing springsheds probably vary substantially by different types and percentages of land use.

Figure 4 shows the nitrate concentrations at baseflow in the East, West, and Main Branches of Trout Brook between 2001-2012. Nitrate levels in the West Branch [as represented by the results of sample TB2] increased at the greatest rate, $0.35 \mathrm{ppm} / \mathrm{year}$. From 2001-2006 nitrate in the East Branch [represented by the sample TB1] increased at a rate of $0.11 \mathrm{ppm} / \mathrm{year}$; however, nitrate concentrations decreased from 2006-2012. The scope of this study did not include further analysis of this phenomenon. The Main Branch [as represented by sample TB3] was collected the furthest downstream and had a nitrate increase of $0.09 \mathrm{ppm} / \mathrm{year}$. The TB3 sample near the end of the Main Branch is a collection of all the water mixing with surface water and groundwater in the streamshed, derived from baseflow and runoff events. At baseflow that water is almost entirely a variable mixture of discrete spring flow and distributed groundwater discharge, as there is no significant surface runoff to Trout Brook during baseflow.

Chloride/bromide ratios are useful in groundwater studies because chloride and bromide are conservative anions that travel with the groundwater and can be used to identify the source water that is recharging the aquifer. Chloride/bromide ratios provide indications of anthropogenic impacts on waters and are explained further by Anger and Alexander (2010).

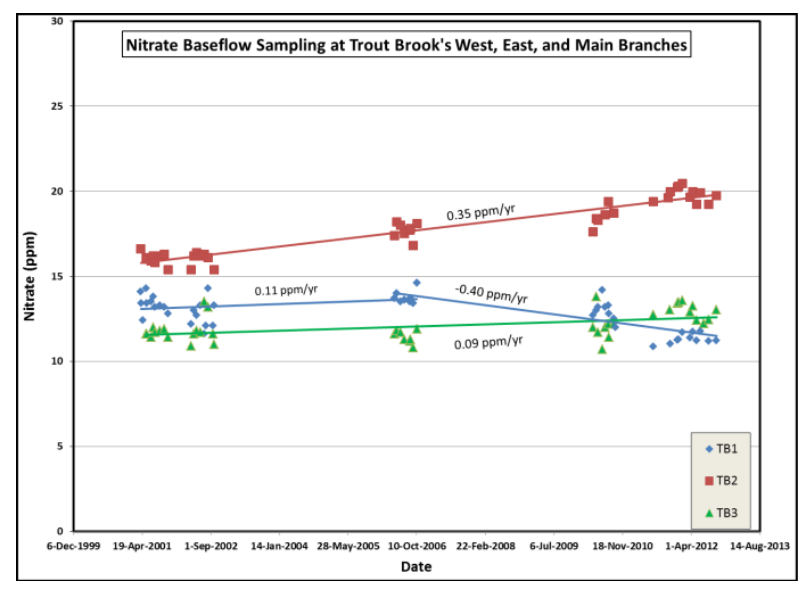

Figure 4. Nitrate baseflow concentration is a function of time at the Main Branch of Trout Brook and its tributairies.

The chloride/bromide ratios of Trout Brook's springs and streams on Figure 5 are averaged values from samples collected from 2011 to 2012. The figure also shows the discrete chloride/bromide ratios of the samples collected in the Main Branch of Trout Brook during the 28 October 2011 synoptic stream flow measurement campaign. The West Branch Springs have the highest ratios indicating the greatest anthropogenic impact. The East Branch Springs have the second highest chloride/bromide ratios. The Main Branch Springs have the lowest ratios.

Figure 5 shows that the chloride/bromide ratios are a function of distance downstream. The chloride/bromide ratios at springs seem to be decreasing towards the southeast. This reduction is occurring from the headwater springs of the West Branch towards Swede Spring.

The 28 October 2011 chloride/bromide ratios show that there was not a significant decrease from the upstream to the downstream end of the Main Branch. The total of all the averaged ratios of the springs are shown as the purple "X." This total averaged value is very similar to the averaged ratios of all samples from TB3 (denoted by the dark green circle), as well as the discrete chloride/bromide ratio of the sample from TB3 on 28 October 2011. This is evidence that the majority of flow from distributed discharge into the stream channel has similar chloride/bromide ratios as the mixed water in the stream channel. The lower chloride/bromide ratios in the Main Branch springs do not significantly lower the chloride/bromide ratios of the mixed water. 


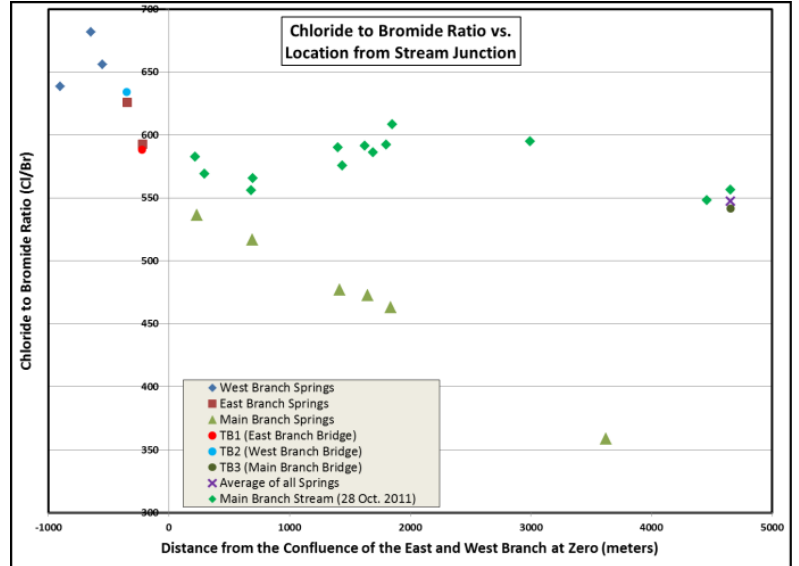

Figure 5. Chloride/bromide ratios are a function of distance from the confluence of East and West Branches of Upper Trout Brook.

Swede Spring has an average chloride/bromide ratio of 348. This is the lowest ratio detected in the springs and is closest to the ratio of rainwater, which varies from 200-250 in Minnesota. The West Branch Springs have the highest ratios, ranging from 630-680. These ratios are comparable to those found in manure and fertilizer (Alexander, 2005).

\section{Runoff Versus Land Use}

Surface water runoff was sampled on 2 March 2012 from the recession of 1.67 inches of rain that occurred on 29 February 2012. Two samples were obtained from two different ravines. Each ravine has its own small watershed, which were delineated using the watershed tool in ArcGIS: ArcMap 10.1. Land use polygons were created using aerial photographs.

In 2011-2012, the smaller watershed (darker green on Figure 2, next to fluorescent green) did not contain any row-crop agriculture while the larger watershed (fluorescent green on Figure 2) contained 40 percent row-crop agriculture. The nitrate concentration was below the detection limit in the samples collected from the watershed with no row-crop agriculture. The samples from the watershed with row-crop agriculture had a nitrate concentration of $10.6 \mathrm{ppm}$.

The $10.6 \mathrm{ppm}$ nitrate in its runoff event from the watershed with row-crop agriculture is consistent with the results in Figure 1. The rapid groundwater velocities and short residence times in karst does not allow enough time for significant nitrate reduction. The nitrate concentrations at springs may be a key indicator of the percent row crop agriculture of their springsheds due to the rapid, direct water flow in karst.

\section{Synoptic Flow and Nitrate Assessment}

A 28-29 October, 2011 synoptic study, of the flow and nitrate levels of Trout Brook at baseflow conditions was conducted. The data were used to understand the interaction between flow and nitrate and to determine if the majority of the flow came from discrete springs or from distributed discharge into the stream channels.

Flow measurements were taken at 32 locations in the Main Branch, tributaries, and springs of Trout Brook to estimate the water contribution from the springs to the overall flow of this trout stream. Measurements were taken upstream and downstream of where the identified springs discharge into East, West, and Main Branches of Trout Brook.

The approximate spring flow was calculated by subtracting the flow of the stream measured upstream of the spring, from the flow measured downstream of the spring. If a spring had formed a channel with enough water, then direct measurements in the spring run were also taken to calculate the flow. All direct flow measurements of the springs were averaged with the flow measurements calculated from the upstream/downstream subtraction. Unfortunately, the flow of some of the springs (with no measureable separate channel) were within the uncertainty of the up and downstream stream flow measurements. In those remaining cases, limits on flow in those spring was visually estimated.

Flow was also measured at particular sites in the stream where a spring was not in proximity. The objective was to distribute the measurements, in order to interpret reaches that may be gaining or losing flow.

Every location where a flow measurement was taken, a water sample was also obtained. Water samples were also retrieved at spring orifices. This was done to understand the mixing concentrations of nitrate and chloride/bromide ratios.

The initial hypothesis that the source of baseflow in the Main Branch of Trout Brook and its tributaries would be primarily from discrete springs is falsified. Data from the two-day synoptic flow measurements show that the majority of the flow is not from discrete springs. Approximately 30-40 percent of the total flow at the sampling point TB3, close to the outlet of Trout Brook, is from spring water. The remaining flow is apparently 
from distributed groundwater discharge into the stream channel because no surface runoff was observed during the synoptic measurements. This result is different from the pattern seen in many southeastern Minnesota trout streams.

The water of Trout Brook is from the mid-Prairie du Chien high transmissivity zone (HTZ). The perennially flowing and gaining reach of Trout Brook is entirely in that HTZ stratigraphic interval. Runkel et al. (2003) and Tipping et al. (2006) have shown that water flows in the HTZ through a broad range of solution enlarged conduits, joints, bedding fractures and other interconnected types of porosity. The larger conduits and flow features are connected to the surface via smaller, more distributed discharge features. The channels of Trout Brook were eroded deeper into the bedrock during the Pleistocene, under conditions of glacial low base levels. Those deeper channels were back-filled with glacial sediments at the end of the last glacial cycle, forming the relatively flat bottom of the Trout Brook Valley. Much of the distributed discharge is in reaches where Trout Brook flows across this sediment backfill.

The spring with the greatest contribution to flow in Trout Brook is Beaver Spring. Beaver Spring discharges into a beaver pond and flows through a swamp before it discharges into the Main Branch at approximately 0.82 cfs. This spring provides only 6.5 percent of the total flow of Trout Brook at the site TB3. The approximated flow from the remaining measured springs can be seen in Table 1 (in Appendix I).

Figure 6 displays nitrate concentration and measured flow versus distance from the confluence of the East and West Branches of Trout Brook. Flow is displayed on the left vertical axis. Nitrate concentration is on the right vertical axis. The horizontal axis displays distance (in meters) along the streams from the confluence of the East and West Branches to form the Main Branch of Trout Brook.

The nitrate concentration decreases only slightly downstream, from $\sim 16 \mathrm{ppm}$ below the confluence to $\sim$ $13 \mathrm{ppm}$ at TB3. In contrast, flow in the Main Branch increases by about a factor of 3 over the same reach, from about $4 \mathrm{cfs}$ to over $12 \mathrm{cfs}$. This relationship can be seen in Figure 6. Distributed groundwater inflow dominates the Main Branch of Trout Brook and the nitrate content of that water is apparently in the 13 to $15 \mathrm{ppm}$ range.
Flow measurements were also taken on 31 March 2012. This was done to see how much flow was gained from the confluence of the East and West Branch to the stream section between Beaver and Hill Springs. The majority of this area was not measured on the 28-29 October 2011 study. It was found that approximately $4.5 \mathrm{cfs}$ of water was gained along this portion of the Main Branch. The only discrete spring in this area is Beaver Spring, which was discharging approximately $0.7 \mathrm{cfs}$ of water into the Main Branch. Approximately $3.8 \mathrm{cfs}$ of water was from distributed discharge into the stream channel.

The majority of flow of Trout Brook is from distributed discharge into the stream channel. However, the flow inputs have changed in Trout Brook. In 1985 the East Branch was contributing more flow to Trout Brook than the West Branch (Spong, 1995) and in 2011 the West Branch was contributing more flow than the East Branch. This illustrates the changes that occur with flow regimes over time. These changes could be from climate, anthropogenic activities such as irrigation, changes in land use, or from changes in the steam channel itself by major floods.

\section{Weber Run Dye Traces}

Weber Run is located in the $\mathrm{E}^{1 / 2}$ of the $\mathrm{SE}^{1 / 4}$ of $\sec 22$ of Douglas Township on private land on the northwest corner of the County Park. Weber Run is shown on Figure 2.

Surface flow in Weber Run is fed by several source springs and then, under all but high flow conditions, sinks completely in a stream sieve (indicated by the

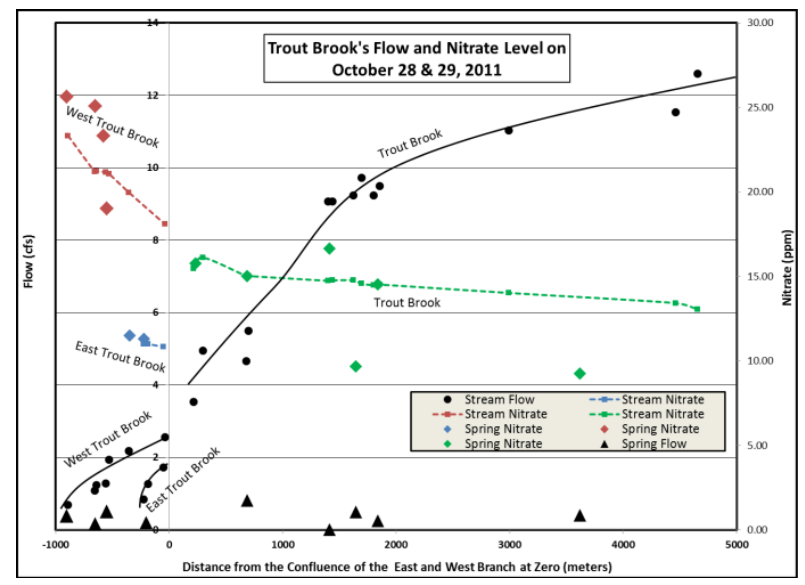

Figure 6. Flow and nitrate concentrations are a function of distance from the confluence of the East and West Branches of Trout Brook. 
blue-dashed line). The source springs (also shown on Figure 2) are a series of small springs and seeps on the southwest stream bank.

On 28 December 2011 Rhodamine WT was introduced in Weber Run. A second dye trace was introduced in Weber Run on 12 April 2012 using eosine dye.

Four positive detections of Rhodamine WT and three positive detections of eosine at LeDuc Spring and one detection of Rhodamine WT confirm that at least a portion of the water of LeDuc and Bridgestone Springs comes from the Weber Sieve area of Weber Run. The 29-day travel time between Weber Sieve and LeDuc Spring measured in the first dye trace corresponds to a groundwater flow velocity of $\sim 27$ meters/day in the southsoutheast direction. The first dye trace also estimated groundwater flow from Weber Sieve to Bridgestone Springs to be 15-20 meters/day. The 79-day travel time between Weber Sieve and LeDuc Spring corresponds to a $\sim 10$ meters/day groundwater velocity during the second dye trace. As the 28 December 2011 and 12 April 2012 traces took place under low flow conditions in an exceptionally dry winter, spring, summer, and fall, the flow velocities under normal, higher flow conditions may be faster.

\section{Conclusion}

Trout Brook is a trout stream in Dakota County's Miesville Ravine Park Reserve. An MPCA survey found Trout Brook had the highest baseflow nitrate concentrations measured in southeastern Minnesota's karst region. This project investigated the karst hydrogeology and water quality in Trout Brook's water to gain information on the source and movement of nitrates through the landscape. This investigation located springs, stream sinks, sinkholes, and other karst phenomena in the Trout Brook watershed. Synoptic surveys of the stream and spring flows. Periodic water samples were collected and analyzed to document nitrate and chloride/bromide ratio time trends. Two dye traces were conducted initiating springshed mapping for the springs. This study combined existing, historical data from 1985 and 1995 with our 2011-2012 results to quantify nitrate time trends for four springs. Data from the 2001, 2002, 2006, and 2010 Dakota SWCD surveys, combined with our 2011-2012 results, permitted documentation of shorter-term time trends for three points in the surface streams. The study period 2011-2012 was abnormally dry but significant floods occurred on 6 May 2012 and 14 -15 June 2012.

Our stream and spring flow measurements indicate that 30-40 percent of the water in Trout Brook is from identified discrete springs. As surface runoff contributes to Trout Brook steam flow only during and immediately after significant precipitation events, distributed groundwater discharge into the stream channel, therefore makes up 60-70 percent of the baseflow.

Nitrate concentrations ranged from about 9 ppm in springs near the downstream end of Trout Brook to over $25 \mathrm{ppm}$ at the upstream springs in the West Branch of Trout Brook. Chloride/ bromide ratios decreased systematically from the upstream springs to the downstream springs. The nitrate concentrations in four of the springs increased at rates ranging from 0.42 to $0.11 \mathrm{ppm} /$ year from 1985 to 2012 . The nitrate concentrations at one upstream site, and the downstream surface water sampling points, have increased at similar rates from 2001 to 2012. The nitrate concentration at another upstream surface water sampling point increased from 2001 to 2006 but decreased from 2006 to 2012 .

Runoff from a 29 February 2012 winter rain event was sampled on 2 March in two small sub-watersheds along the East Branch of Trout Brook. Runoff from a sub-watershed containing only forest and CRP land contained no detectable nitrate. Runoff from a sub-watershed that was 40 percent row-crop land contained $10.6 \mathrm{ppm}$ nitrate.

Dye tracing documented karst aquifer flow-paths from the Weber Run stream sieve to LeDuc and Bridgestone Springs with flow velocities in the range of 15 to 27 meters per day.

The results of this study indicate that row-crop agriculture in the surface and subsurface drainage basins of Trout Brook is the primary cause of the water's elevated concentrations of nitrate. This conclusion is supported by the MPCA's correlation between the percentages of row-crop agriculture and the nitrate concentrations in run-off and stream samples. 